\title{
Arbuscular mycorrhizal fungi and colonization stimulant in cotton and maize
}

\author{
Fabrício Henrique Moreira Salgado ${ }^{1}$ Fátima Maria de Sousa Moreira $^{2}$ José Oswaldo Siqueira ${ }^{3}$ \\ Ricardo Henrique Barbosa ${ }^{2}$ Helder Barbosa Paulino ${ }^{4}$ Marco Aurélio Carbone Carneiro ${ }^{2 *}$
}

\author{
${ }^{1}$ Agência de Defesa Agropecuária do Estado do Tocantins, Gurupi, TO, Brasil. \\ ${ }^{2}$ Universidade Federal de Lavras (UFLA), Departamento de Ciência do Solo, CP 3037, 37200-000, Lavras, MG, Brasil. E-mail: \\ marcocarbone@dcs.ufla.br. "Corresponding author. \\ ${ }^{3}$ Universidade Federal de Lavras (UFLA) e Instituto Tecnológico Vale, Belém, PA, Brasil. \\ ${ }^{4}$ Universidade Federal do Triângulo Mineiro (UFTM), Iturama, MG, Brasil.
}

\begin{abstract}
The objective of this study was to evaluate the effects of inoculation with different arbuscular mycorrhizal fungi native to Cerrado, associated with the application of colonization stimulant (7-hydroxy, 4'-methoxy-isoflavone) at the initial growth of cotton and maize plants in a greenhouse. The experiment was carried out in a completely randomized design and $7 x 2$ factorial scheme, with five species of arbuscular mycorrhizal fungi and combined inoculation (uniting all species in equal proportion) and native fungi, in the presence and absence of colonization stimulant in maize and cotton crops. Shoots dry matter (SDM), roots dry matter (RDM), mycorrhizal colonization and accumulation of calcium, zinc and phosphorus in the SDM were evaluated at flowering. Inoculation of arbuscular mycorrhizal fungi and the use of colonization stimulant at low density of arbuscular mycorrhizal fungi propagules was beneficial to plant development. Inoculation with mycorrhizal fungi demonstrated different effects for the various parameters evaluated in cotton and maize, and the application of colonization stimulant promoted higher mycorrhizal colonization and initial growth in cotton, when associated with native AMF, and in corn, when associated with inoculation with Dentiscutata heterogama, Gigaspora margarita and Rhizophagus clarus.
\end{abstract}

Key words: Zea may, Gossypium hirsutum L., Formononetin, mycorrhiza.

Fungos micorrízicos arbusculares e estimulante da colonização na cultura do algodoeiro e do milho

RESUMO: O objetivo deste estudo foi avaliar os efeitos da inoculação com diferentes fungos micorrízicos arbusculares nativos do Cerrado, associados à aplicação de estimulante de colonização (7-hidroxi, 4'-metoxi-isoflavona) no crescimento inicial de plantas de algodão e milho em casa de vegetação. O experimento foi conduzido em delineamento inteiramente casualizado e esquema fatorial $7 x 2$, com cinco espécies de fungos micorrízicos arbusculares e inoculação combinada (unindo todas as espécies em proporção igual) e fungos nativos, na presença e ausência de estimulante de colonização em culturas de milho e algodão. Avaliou-se a massa de matéria seca (SDM), matéria seca de raízes (RDM), colonização micorrízica e acúmulo de cálcio, zinco e fósforo na SDM. A inoculação com fungos micorrízicos arbusculares e o uso de estimulante de colonização em baixa densidade de propágulos de fungos micorrízicos arbusculares foi benéfico para o desenvolvimento da planta. A inoculação com fungos micorrízicos mostrou efeitos diferentes para os vários parâmetros avaliados no algodão e no milho, e a aplicação de estimulante de colonização promoveu maior colonização micorrízica e crescimento inicial no algodão quando associado à fungos micorrízicos arbusculares nativa e no milho quando associado à inoculação com Dentiscutata heterogama, Gigaspora margarita e Rhizophagus clarus.

Palavras-chave: Zea mays, Gossypium hirsutum L., Formononetina, Micorriza.

\section{INTRODUCTION}

Several research programs have studied soil biological resources in order to increase the efficiency of fertilizers and the sustainability of agroecosystems. Among these resources, the arbuscular mycorrhizal fungi (AMF), which are obligate symbionts belonging to the phylum Glomeromycota (SCHÜBLER et al., 2001), stand out for colonizing the roots of most terrestrial plants. The
AMF can exploit a large volume of soil, even outside the root system influence zone, by using their hyphae network, allowing greater absorption of water and nutrients, especially those of low soil mobility, such as phosphorus (MOREIRA \& SIQUEIRA, 2006).

For the soils of the Cerrado biome, which are of low natural fertility, the mycorrhizal association may increase grain, fiber, and energy yield (ASSIS et al., 2014). Cotton and maize crops stood out for demanding high amounts of fertilizers, 
mainly phosphates, and for being responsive to AMF (THOMPSON et al., 2012). In this sense, the adoption of strategies that maximize natural resources, such as phosphate fertilizers, by using mycorrhizal fungi, can reduce costs and increase yield (DAVIES et al., 2005).

Despite the recognized importance, AMF have not been yet multiplied in large scale in laboratories, due to the condition of obligate symbionts, which hinders their biotechnological use (CORDEIRO et al. 2015). Discovery of chemical substances capable of acting as biochemical signals, and as mycorrhizal colonization biostimulant, such as the isoflavone formononetin (NAIR et al., 1991; SIQUEIRA et al., 1991), are alternatives to maximize the benefits of native AMF in nutritional improvement of cultivated plants, and reduction of biotic and abiotic stresses.

Several laboratory studies have confirmed the beneficial effects of the application of colonization stimulant (NOVAIS \& SIQUEIRA, 2009). In a field study in the Cerrado region of the state of Goiás, CORDEIRO et al. (2015) demonstrated that the application of colonization stimulant (formononetin) via soybean seed increased mycorrhizal root colonization, number of nodules and soybean yield, and also reduced the negative effects of the Carbendazim + Thiram fungicides, showing the potential of this substance.

The importance of diversity and the symbiotic and infective potential of native AMF in Brazilian ecosystems are not widely known, and the use of chemical compounds that stimulate these fungi to promote plant growth can be a strategy to increase fertilizer use efficiency, mainly phosphate, and crop yield.

Therefore, the objective of this study was to evaluate the effects of inoculation with different arbuscular mycorrhizal fungi native to Cerrado associated with the application of colonization stimulant (7-hydroxy, 4'-methoxy isoflavone) at the initial growth of cotton and maize plants in a greenhouse.

\section{MATERIALS AND METHODS}

The experiment was carried out in the greenhouse, in a completely randomized design, in a $7 \times 2$ factorial scheme, with 5 AMF species, combined inoculation (uniting all species in equal proportion), and native fungi (without inoculation) in the presence or absence of colonization stimulant, in 5 replications.

AMFs spores were collected in soils of the Cerrado biome $\left(17^{\circ} 56^{\prime} 35^{\prime \prime} \mathrm{S}\right.$; $51^{\circ} 43^{\prime} 38^{\prime \prime} \mathrm{W}$, at $672 \mathrm{~m}$ asl, Southwest region of Goiás). Spores were isolated and identified as Acaulospora scrobiculata, Claroideoglomus etunicatum, Dentiscutata heterogama, Gigaspora margarita and Rhizophagus clarus. Each species was multiplied for eight months in a culture pot using Urochloa brizantha (Hochst. ex A. Rich.) R.D. Webster as host plant.

The soil was classified as Dystrophic Red Latosol, collected on the subsurface layer (at 60 to $80 \mathrm{~cm}$ depth), corrected with dolomitic limestone, incubated for 30 days. Afterwards, it was chemically and physically characterized, as follows: $\mathrm{pH}\left(\mathrm{H}_{2} \mathrm{O}\right)$ $=6.3, \mathrm{~K}=12 \mathrm{mg} \mathrm{dm}^{-3} ; \mathrm{P}($ Mehlich 1$)=0.01 \mathrm{mg} \mathrm{dm}^{-3} ; \mathrm{Ca}$ $=2.10 \mathrm{cmol}_{\mathrm{c}} \mathrm{dm}^{-3} ; \mathrm{Mg}=0,50 \mathrm{cmol} \mathrm{dm}^{-3} ; \mathrm{Al}=0.01 \mathrm{cmol}_{\mathrm{c}}$ $\mathrm{dm}^{-3} ; \mathrm{H}+\mathrm{Al}=1.86 \mathrm{cmol}_{\mathrm{c}} \mathrm{dm}^{-3}$; clay $=690 \mathrm{~g} \mathrm{~kg}^{1}$; silt $=$ $140 \mathrm{~g} \mathrm{~kg}^{1}$, and sand $=170 \mathrm{~g} \mathrm{~kg}^{1}$. Density of native AMF spores in the soil was determined by wet sieving (GERDEMANN \& NICOLSON, 1963) and 5 unidentified AMF spores per $50 \mathrm{dm}^{-3}$ of soil were reported.

Fertilization was carried out considering only $50 \%$ of the recommended phosphate fertilization, by applying $125,100,80$ and 80,120 and $60 \mathrm{~kg} \mathrm{ha}^{-1}$ of $\mathrm{N}, \mathrm{P}_{2} \mathrm{O}_{5}$ and $\mathrm{K}_{2} \mathrm{O}$, respectively, and $2 ; 10 ; 0.01 ; 0.03$; 1 and $0.02 \mathrm{~kg} \mathrm{ha}^{-1}$ zinc, magnesium, boron, copper, manganese and molybdenum, respectively, to both crops (SOUSA \& LOBATO, 2004). Urea was used as nitrogen source.

Seeds of the cultivar 'FMT 701' (Gossypium hirsutum) were used for cotton, and seeds of the single hybrid 30S31 were used for maize (Zea mays). Seeds were sterilized for 30 seconds in alcohol, two minutes in $2 \%$ sodium hypochlorite, and subsequently rinsed in sterile water. After disinfestation, seeds were subjected to the proposed treatments. The colonization stimulant (Formononetin =7-hydroxy, 4'-methoxy-isoflavone) was applied to the seed considering $2.8 \mathrm{~g} \mathrm{~kg}^{-1}$ of maize seed and $0.9 \mathrm{~g}$ $\mathrm{kg}^{-1}$ of cotton seed.

Sowing was carried out on August $19^{\text {th }}$, 2013, and three seeds were sown in $3 \mathrm{~kg}$ pot. On top of each seed, $1 \mathrm{~mL}$ of solution containing 100 spores of arbuscular mycorrhizal fungi (AMF) was inoculated with the aid of a pipette. For inoculation, 100 spores per $1 \mathrm{~mL}$ of each AMF were studied. In the combined Inoculation, 100 spores per $1 \mathrm{ml}$ of a mixture were added, in the same proportion of all studied AMFs. One $\mathrm{mL}$ of the solution without spores was added to the control treatment. Each pot consisted of two plants for cotton and one plant for maize. Humidity was maintained at $60 \%$ of the total pore volume by periodic weighing.

The study was carried out until the flowering stage of each crop, corresponding to 45 and 
50 days for cotton and maize, respectively. Shoots and roots were collected, washed in distilled water, stored in paper bags, and allowed to dry in forced air circulation oven at $60^{\circ} \mathrm{C}$, for 72 hours, in order to obtain shoots dry matter (SDM) and roots dry matter (RDM). SDM was ground in a Wiley mill for the determination of calcium, zinc and phosphorus, according to MALAVOLTA et al. (1997). One gram of fresh roots was collected, clarified with $\mathrm{KOH}$, and stained with methyl blue (KOSKE \& GEMMA, 1989) for the evaluation of mycorrhizal colonization (GIOVANNETTI \& MOSSE, 1980).

The experimental data were subjected to individual analysis, and subsequently, to joint analysis of variance, under conditions of homogeneity of the residual variances, using the $\mathrm{F}$ test. Only the mycorrhizal colonization was transformed by the equation $(x+0.5)^{0.5}$. The ScottKnott test was applied at 5\% for means comparison, using the SISVAR software.

\section{RESULTS AND DISCUSSION}

All inoculated arbuscular mycorrhizal fungi (AMF) promoted higher colonization than native AMF (Figure 1). For cotton, the highest mycorrhizal colonization was observed in the combined inoculation and Rhizophagus clarus. For maize, the highest colonization occurred with Dentiscutata heterogama, in the presence of colonization stimulant, and in the combined inoculation, regardless of the application of mycorrhizal colonization stimulant.

The use of colonization stimulant increased mycorrhizal colonization, except in plants inoculated with Gigaspora margarita in maize, and with D. heterogama and $R$. clarus in cotton. Mycorrhizal colonization was observed in the non-inoculated treatment $(<8 \%)$ provided by the native AMF, being greater in the presence of mycorrhizal stimulant for both crops, which corroborated the study of CORDEIRO et al. (2015) in Cerrado soil.

In cotton, the fungi Acaulospora scrobiculata, Claroideoglomus etunicatum, and Gigaspora margarita and the combined inoculation increased shoot dry matter (SDM) in the absence of stimulant (Table 1). This difference of response obtained with different fungi was also observed by BADDA et al. (2015), and confirmed the importance of a greater diversity of AMF in the soil. Although, there is no specificity between AMF and host plant, the efficiency in growth promotion varies according to the fungus and to the host plant.
The application of colonization stimulant increased $91 \%$ SDM in cotton plants with native AMF, differing significantly $(\mathrm{P} \leq 0.05)$ from the treatment with no colonization stimulant (Table 1). This is, despite the low mycorrhizal colonization, it was sufficient and efficient in increasing SDM. Studies have demonstrated higher effect of colonization stimulant in soils with low spore density (DAVIES et al., 2005; CORDEIRO et al., 2015), corroborating the present results.

In corn, inoculation with $C$. etunicatum provided higher SDM growth in relation to the treatments without stimulant (Table 1). Application of colonization stimulant promoted an increase in SDM of 117, 44 and $22 \%$ when inoculated with $D$. heterogama, G. margarita and R. clarus, respectively; and of $11 \%$ in the treatment that contained only native AMF, in relation to the absence of colonization stimulant.

For cotton, root dry matter (RDM) in the absence of stimulant was positively influenced by the inoculation with C. etunicatum, D. heterogama, $G$. margarita and by the combined inoculation (Table 1). When stimulant was applied, only the combined inoculation and $R$. clarus increased 38 and $59 \%$, respectively, in relation to native AMF.

A study carried out in Australia in soil subjected to monoculture for several years demonstrated the importance of native AMF for the development and production of cotton (THOMPSON et al., 2012). Considering that the root system of this crop has little capacity to exploit the soil, when the soil presents low density of viable spores of native AMF, the application of colonization stimulant is a strategy to promote greater absorption of water and nutrients, and to increase the growth in cotton, as observed in the present study.

In the absence of stimulant in the maize crop, all the inoculated AMF significantly increased RDM, except $D$. heterogama, which did not differ from the native AMF (Table 1). When stimulant was applied, only the inoculation with $G$. margarita differed significantly from native AMF.

The application of stimulant in the cotton associated with $R$. clarus, in the combined inoculation, and in the native AMF increased RDM by 59,38 and $28 \%$ in relation to the absence of stimulant of colonization. In maize, the effect was higher, with increase of 243,144, 32 and $74 \%$ in the inoculation with D. heterogama, G. margarita, $R$. clarus and in combined inoculation, and of $153 \%$ in the treatment with native AMF.

The increase of RDM is a strategy for the crops to withstand environmental stresses, especially 


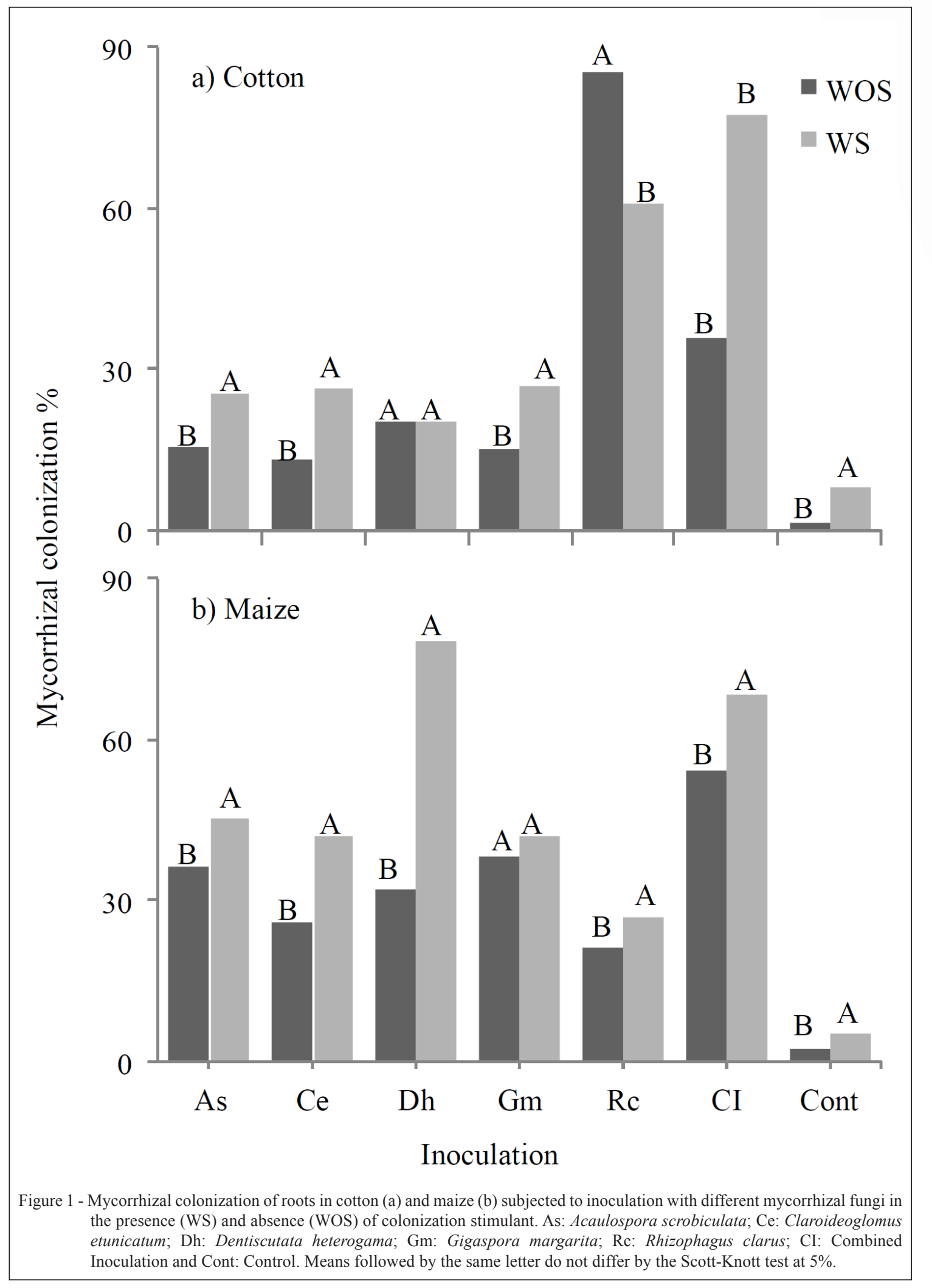

Ciência Rural, v.47, n.6, 2017. 
Table 1 - Shoot dry matter (SDM), root dry matter (RDM) of cotton and corn, without colonization stimulant (WOS) and with colonization stimulant (WS).

\begin{tabular}{|c|c|c|c|c|}
\hline \multirow{3}{*}{ Fungi } & WOS & WS & WOS & WS \\
\hline & \multicolumn{4}{|c|}{ 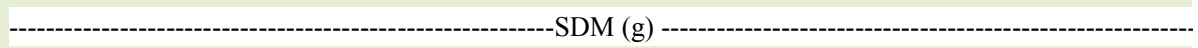 } \\
\hline & \multicolumn{4}{|c|}{----------------------------Cotton--------------------------- --------------------------------Maize---------------. } \\
\hline Acaulospora scrobiculata & $3.05 \mathrm{aA}$ & $2.83 \mathrm{aA}$ & $8.83 \mathrm{dA}$ & $9.02 \mathrm{dA}$ \\
\hline Claroideoglomus etunicatum & $2.76 \mathrm{aA}$ & $2.81 \mathrm{aA}$ & $13.95 \mathrm{aA}$ & $11.07 \mathrm{cB}$ \\
\hline Dentiscutata heterogama & $1.48 \mathrm{bA}$ & $1.97 \mathrm{bA}$ & $4.46 \mathrm{~dB}$ & $9.67 \mathrm{dA}$ \\
\hline Gigaspora margarita & $2.86 \mathrm{aA}$ & $2.72 \mathrm{aA}$ & $8.58 \mathrm{cB}$ & $12.41 \mathrm{bA}$ \\
\hline Rhizophagus clarus & $1.97 \mathrm{bA}$ & $2.30 \mathrm{bA}$ & $10.42 \mathrm{cB}$ & $12.72 \mathrm{bA}$ \\
\hline Combined inoculation & $3.17 \mathrm{aA}$ & $2.93 \mathrm{aA}$ & $11.51 \mathrm{cA}$ & $11.19 \mathrm{cA}$ \\
\hline \multirow[t]{3}{*}{ Control } & $1.76 \mathrm{bB}$ & $3.36 \mathrm{aA}$ & $12.46 \mathrm{bB}$ & $13.89 \mathrm{aA}$ \\
\hline & \multicolumn{4}{|c|}{ 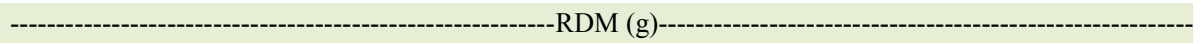 } \\
\hline & -----------. & ----------. & ----------- & ----------- \\
\hline Acaulospora scrobiculata & $0.33 \mathrm{bA}$ & $0.38 \mathrm{cA}$ & $4.69 \mathrm{aA}$ & $5.72 \mathrm{bA}$ \\
\hline Claroideoglomus etunicatum & $0.37 \mathrm{aA}$ & $0.39 \mathrm{cA}$ & $3.43 \mathrm{bA}$ & $4.67 \mathrm{bA}$ \\
\hline Dentiscutata heterogama & $0.40 \mathrm{aA}$ & $0.41 \mathrm{cA}$ & $1.66 \mathrm{cB}$ & $5.70 \mathrm{bA}$ \\
\hline Gigaspora margarita & $0.37 \mathrm{aA}$ & $0.37 \mathrm{cA}$ & $3.09 \mathrm{bB}$ & $7.57 \mathrm{aA}$ \\
\hline Rhizophagus clarus & $0.32 \mathrm{bB}$ & $0.51 \mathrm{bA}$ & $3.95 \mathrm{aB}$ & $5.20 \mathrm{bA}$ \\
\hline Combined inoculation & $0.45 \mathrm{aB}$ & $0.62 \mathrm{aA}$ & $2.95 \mathrm{bB}$ & $5.09 \mathrm{bA}$ \\
\hline Control & $0.29 \mathrm{bB}$ & $0.37 \mathrm{cA}$ & $1.85 \mathrm{cB}$ & $4.69 \mathrm{bA}$ \\
\hline
\end{tabular}

Means followed by the same uppercase letters in the row and lowercase letters in the column do not differ by the Scott-Knott test at $5 \%$.

water, which is very common in the Midwest region of Brazil. In this sense, the association between mycorrhizal colonization stimulant and inoculation with AMF provided mean increases of $21 \%$ and $101 \%$ for cotton and maize, respectively. $R$. clarus stood out in the cotton crop, with increase of $50 \%$; and $D$. heterogama and G. margarita stood out in the maize crop, with increase greater than $100 \%$.

This increase in the root system promotes greater soil exploration by the plants, and consequently, greater absorption of water and nutrients, besides contributing to the accumulation of carbon in the soil by means of root decomposition and root death. In this sense, the RDM estimates obtained in this study show that native AMF would contribute with $387 \mathrm{~kg} \mathrm{ha}^{-1} \mathrm{RDM}$ in the cotton crop, and with $2,476 \mathrm{~kg} \mathrm{ha}^{-1} \mathrm{RDM}$ in the maize crop. Moreover, an increase of $107 \mathrm{~kg}$ $\mathrm{ha}^{-1}$ and $3,786 \mathrm{~kg} \mathrm{ha}^{-1}$ MSR in cotton and maize, respectively, would only occur with stimulant application, representing a significant increase in the roots; and consequently a contribution with the accumulation of carbon in the soil.

The highest calcium accumulation in SDM was observed in the absence of stimulant when cotton plants were inoculated with G. margarita and in combined inoculation, differing significantly $(\mathrm{P} \leq 0.05)$ from native AMF. However, when stimulant was applied, the greatest accumulation was verified in the treatment with native AMF (Table 2).

In maize, native AMF and the inoculation with $A$. scrobiculata and C. etunicatum in the absence of colonization stimulant provided higher calcium accumulation in SDM. However, only $R$. clarus significantly differed from the other treatments when stimulant was applied.

In the cotton crop, in the absence of stimulant, the inoculation with $A$. scrobiculata, $C$. etunicatum, and $G$. margarita, and the combined inoculation promoted higher accumulation of $\mathrm{Zn}$ in SDM in relation to native AMF (Table 2). The same was observed for the maize crop in the inoculation with $A$. scrobiculata and $R$. clarus. In the presence of stimulant, the treatments with native AMF, $C$. etunicatum and G. margarita presented greater $\mathrm{Zn}$ accumulation in cotton, and only the combined inoculation did not increase $\mathrm{Zn}$ accumulation in maize.

Plants inoculated with $D$. heterogama and $R$. clarus in cotton, and with A. scrobiculata and $D$. heterogama in maize did not present higher phosphorus accumulation in the absence of colonization stimulant (Table 2). In the presence of stimulant, no difference was observed for $\mathrm{P}$ accumulation in cotton; in maize, native AMF provided greater $\mathrm{P}$ accumulation in SDM. The association between stimulant and inoculation with 
Table 2 - Accumulation of calcium, zinc and phosphorus in the shoot of the cotton cultivar FMT 701, and of the maize single hybrid 30S31, without colonization stimulant (WOS) and with colonization stimulant (WS) (formononetin).

\begin{tabular}{|c|c|c|c|c|}
\hline \multirow{3}{*}{ Fungi } & WOS & WS & WOS & WS \\
\hline & \multicolumn{4}{|c|}{ 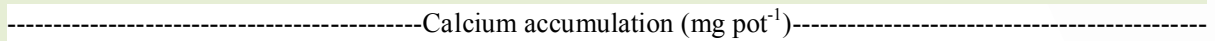 } \\
\hline & \multicolumn{4}{|c|}{ 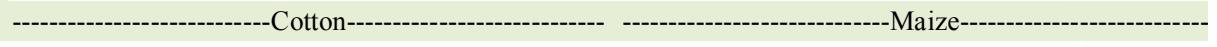 } \\
\hline Acaulospora scrobiculata & $26.1 \mathrm{bA}$ & $28.5 \mathrm{bA}$ & $54.9 \mathrm{aA}$ & $45.7 \mathrm{bA}$ \\
\hline Claroideoglomus etunicatum & $24.8 \mathrm{bA}$ & $28.6 \mathrm{bA}$ & $61.2 \mathrm{aA}$ & $54.6 \mathrm{bA}$ \\
\hline Dentiscutata heterogama & $17.3 \mathrm{bB}$ & $28.0 \mathrm{bA}$ & $22.9 \mathrm{cB}$ & $51.8 \mathrm{bA}$ \\
\hline Gigaspora margarita & $40.9 \mathrm{aA}$ & $32.3 \mathrm{bA}$ & $48.1 \mathrm{bA}$ & $51.0 \mathrm{bA}$ \\
\hline Rhizophagus clarus & $21.8 \mathrm{bA}$ & $26.8 \mathrm{bA}$ & $44.5 \mathrm{bB}$ & $70.2 \mathrm{aA}$ \\
\hline Combined inoculation & $38.4 \mathrm{aA}$ & $32.0 \mathrm{bA}$ & $44.4 \mathrm{bA}$ & $46.3 \mathrm{bA}$ \\
\hline \multirow[t]{3}{*}{ Control } & $24.3 \mathrm{bB}$ & $40.7 \mathrm{aA}$ & $63.1 \mathrm{aA}$ & $41.6 \mathrm{bB}$ \\
\hline & \multicolumn{4}{|c|}{ 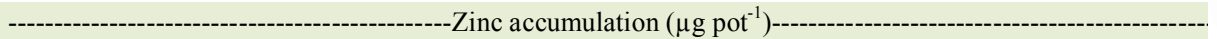 } \\
\hline & \multicolumn{4}{|c|}{ 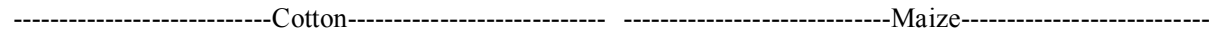 } \\
\hline Acaulospora scrobiculata & $57.3 \mathrm{aA}$ & $60.7 \mathrm{bA}$ & $86.1 \mathrm{bB}$ & $112.1 \mathrm{bA}$ \\
\hline Claroideoglomus etunicatum & $59.7 \mathrm{aB}$ & $85.7 \mathrm{aA}$ & $50.2 \mathrm{cB}$ & $250.6 \mathrm{aA}$ \\
\hline Dentiscutata heterogama & $28.9 \mathrm{bA}$ & $44.1 \mathrm{bA}$ & $25.8 \mathrm{cB}$ & $97.4 \mathrm{bA}$ \\
\hline Gigaspora margarita & $73.0 \mathrm{aA}$ & $74.5 \mathrm{aA}$ & $58.9 \mathrm{cA}$ & $73.2 \mathrm{cA}$ \\
\hline Rhizophagus clarus & $44.4 \mathrm{bA}$ & $57.4 \mathrm{bA}$ & $203.0 \mathrm{aA}$ & $72.5 \mathrm{cB}$ \\
\hline Combined inoculation & $74.5 \mathrm{aA}$ & $57.6 \mathrm{bA}$ & $39.9 \mathrm{cB}$ & $60.1 \mathrm{dA}$ \\
\hline \multirow[t]{3}{*}{ Control } & $43.2 \mathrm{bB}$ & $71.8 \mathrm{aA}$ & $30.5 \mathrm{cA}$ & $46.1 \mathrm{dA}$ \\
\hline & \multicolumn{4}{|c|}{ 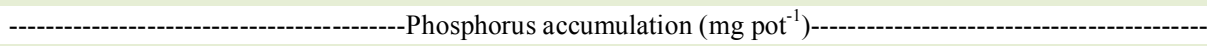 } \\
\hline & - & ------.-- & -----------. & --------- \\
\hline Acaulospora scrobiculata & $2.7 \mathrm{aA}$ & $2.8 \mathrm{aA}$ & $14.4 \mathrm{cA}$ & $16.9 \mathrm{cA}$ \\
\hline Claroideoglomus etunicatum & $3.0 \mathrm{aA}$ & $2.3 \mathrm{aA}$ & $24.6 \mathrm{aB}$ & $21.3 \mathrm{bA}$ \\
\hline Dentiscutata heterogama & $1.2 \mathrm{bB}$ & $2.2 \mathrm{aA}$ & $10.3 \mathrm{~dB}$ & $16.5 \mathrm{cA}$ \\
\hline Gigaspora margarita & $2.9 \mathrm{aA}$ & $2.4 \mathrm{aA}$ & $18.6 \mathrm{bA}$ & $19.8 \mathrm{bA}$ \\
\hline Rhizophagus clarus & $2.1 \mathrm{bB}$ & $2.9 \mathrm{aA}$ & $17.1 \mathrm{bA}$ & $20.1 \mathrm{bA}$ \\
\hline Combined inoculation & $2.6 \mathrm{aA}$ & $2.5 \mathrm{aA}$ & $17.8 \mathrm{bA}$ & $17.2 \mathrm{cA}$ \\
\hline Control & $1.7 \mathrm{bB}$ & $2.6 \mathrm{aA}$ & $19.4 \mathrm{bB}$ & $24.3 \mathrm{aA}$ \\
\hline
\end{tabular}

Means followed by the same uppercase letters in the row and lowercase letters in the column do not differ by the Scott-Knott test at $5 \%$.

$D$. heterogama and R. clarus in cotton, and with $C$. etunicatum and D. heterogama in maize was beneficial, providing greater $\mathrm{P}$ accumulation, which is also observed in native AMF.

Strategies that provided greater absorption and accumulation of $\mathrm{Ca}, \mathrm{Zn}$ and $\mathrm{P}$ reflect in greater development and production, since these nutrients are essential for the growth of maize and cotton (ROSOLEM \& BASTOS, 1997). In this sense, results demonstrated that the inoculation with AMFs was beneficial and efficient when the soil presents low density of viable spores of native AMFs, as in the present study. However, inoculation with AMFs is still economically unfeasible, due to its obligatory biotrophism, which makes the use of the colonization stimulant an alternative, since native AMF are stimulated to efficiently colonize the roots and to increase the development of crops, as presented in this study for cotton and maize.
Results indicated that the native AMF benefited from the application of stimulant in relation to treatments inoculated with exotic AMF. The ability to promote the growth of cotton and maize plants differed with the inoculation of different AMFs introduced from native AMF, corroborating with other studies (CORDEIRO et al., 2015; GRUNWALD et al. 2009).

Cotton plants, in the absence of stimulant, benefited from inoculation with different AMF species. When the stimulant was not applied, the plants inoculated with several AMFs presented higher colonization, absorption and accumulation of $\mathrm{Zn}$ and $\mathrm{P}$, which resulted in greater shoot development and root production. Inoculation with $A$. scrobiculata, $C$. etunicatum and G. margarita also increased SDM, with the exception of mycorrhizal colonization. However, in the presence of stimulant, this effect was lower, 
being more evident the benefits in the treatment without AMF inoculation.

Maize presented small effect when inoculated with the different AMFs, both in the presence and absence of stimulant. Only C. etunicatum stood out as the species that most provided benefits to this crop in the absence of colonization stimulant. These results may be related to the genetics of the studied cultivar, since most are developed for growth with high fertilization, losing capacity to express and respond to biological resources, such as AMF, a fact reported in the literature and that corroborated the present study (REIS et al., 2008).

\section{CONCLUSION}

In soil with low density of native AMF, inoculation with exotic AMF and application of mycorrhizal colonization stimulants were beneficial to the development of cotton and maize plants. Inoculation with arbuscular mycorrhizal fungi demonstrated different effects depending on the parameters evaluated in cotton and maize. The application of colonization stimulant promoted greater mycorrhizal colonization and initial growth in cotton when associated with native AMF, and in maize when associated with Dentiscutata heterogama, Gigaspora margarita and Rhizophagus clarus.

\section{ACKNOWLEDGEMENTS}

The authors acknowledge Fundação de Amparo à Pesquisa do Estado de Minas Gerais (FAPEMIG), Conselho Nacional de Desenvolvimento Científico e Tecnológico (CNPq) and Coordenação de Aperfeiçoamento de Pessoal de Nível Superior (CAPES) for scholarships and research fellowship.

\section{REFERENCES}

ASSIS, P.C.R. et al. Arbuscular mycorrhizal fungi in "murundu fields" after conversion to farm systems in the cerrado. Revista Brasileira de Ciência do Solo, v.38, n.6, p.1703-1711, 2014. Available from: <http://www.sbcs.org.br/wp-content/ uploads/2014/12/V38N6a05.pdf>. Accessed: Mar. 14, 2017. doi: $10.1590 / \mathrm{S} 0100-06832014000600005$.

BADDA,N. et al. Consortium effect of arbuscular mycorrhizal fungi and pseudomonas fluorescens with various levels of superphosphate on growth improvement of cotton (G. arboreum L.). Journal of Natural Fibers, v.12, n.1, p.12-25., 2015. Available from: <http://www.tandfonline.com/doi/abs/10.10 80/15440478.2013.879085>. Accessed: Mar. 14, 2017. doi: $10.1080 / 15440478.2013 .879085$.

CORDEIRO, M.A.S. et al. Mycorrhization stimulant based in formononetin associated to fungicide and doses of phosphorus in soybean in the Cerrado. Bioscience Journal, v.31, n.4, p.10621070, 2015. Available from: <http://www.seer.ufu.br/index.php/ biosciencejournal/article/view/26185>. Accessed: Mar. 10, 2017. doi: 10.14393/BJ-v31n4a2015-26185.

DAVIES, F.T et al. Influence of a flavonoid (formononetin) on mycorrhizal activity and potato crop productivity in the highlands of Peru. Scientia Horticulturae, v.106, n.3, p.318-329, 2005. Available from: $<$ http://www.sciencedirect.com/science/article/pii/ S0304423805001597>. Accessed: Mar. 10, 2017. doi: 10.1016/j. scienta.2005.04.013.

GERDEMANN, J.W.; NICOLSON, T.H. Spores of mycorrhizal endogone species extracted from spil by wet-sieving and decanting. Transactions of British Mycological Society, v.46, n.2, p.235-244, 1963. Available from: <http://www.sciencedirect. com/science/article/pii/S0007153663800790>. Accessed: Mar. 14, 2017. doi: 10.1016/S0007-1536(63)80079-0.

GIOVANNETTI, M.; MOSSE, B. An evaluation of techniques to measure vesicular-arbuscular mycorrhizal infection in roots. New Phytologist, v.84, n.3, p.489-500, 1980. Available from: <http:// onlinelibrary.wiley.com/doi/10.1111/j.1469-8137.1980.tb04556.x/ abstract>. Accessed: Mar. 14, 2017. doi: 10.1111/j.14698137.1980.tb04556.x

GRUNWALD, W.G. et al. Overlapping expression patterns and differential transcript levels of phosphate transporter genes in arbuscular mycorrhizal, Pi-fertilised and phytohormone-treated Medicago truncatula roots. Planta, v.229, n.5, p.1023-1034, 2009. Available from: <https://link.springer.com/article/10.1007/ s00425-008-0877-z >. Accessed: Mar. 10, 2017. doi: 10.1007/ s00425-008-0877-z.

KOSKE, R.E.; GEMMA, J.N. A modified procedure for staining roots to detect VA mycorrhizas. Mycological Research, v.92, n.4, p.486-488, 1989. Available from: <http://www.sciencedirect. com/science/article/pii/S0953756289801959>. Accessed: Mar. 08, 2017. doi: 10.1016/S0953-7562(89)80195-9.

MALAVOLTA, E. et al. Avaliação do estado nutricional das plantas: princípios e aplicações. Piracicaba: Associação Brasileira para a Pesquisa da Potassa e do Fosfato, 1997. p.319.

MOREIRA, F.M.S.; SIQUEIRA, J.O. Microbiologia e bioquímica do solo. 2 ed. Lavras: UFLA, 2006. p.729.

NOVAIS, C.B.; SIQUEIRA, J.O. Formononetin application on colonization and sporulation of arbuscular mycorrhizal fungi in Brachiaria. Pesquisa Agropecuária Brasileira, v.44, n.5, p.496-502, 2009. Available from: <http://www. scielo.br/scielo.php? script $=$ sci_arttext\&pid=S $0100-$ 204X2009000500009>. Accessed: Mar. 14, 2017. doi: 10.1590/ S0100-204X2009000500009.

NAIR, M.G. et al. Isolation and identification of vesicular-arbuscular mycorrhiza-stimulatory compounds from clover (Trifolium repens) roots. Applied and Environmental Microbiology, v.57, n.2, p.434-439, 1991. Available from: <https://www.ncbi.nlm.nih.gov/ pmc/articles/PMC182728/>. Accessed: Mar. 14, 2017. doi: 00992240/91/020434-06\$02.00/0.

REIS, E.F. et al. Phosphorus absorption in twelve corn genotypes inoculated with arbuscular mycorrhizal fungus in cerrado soil. Ciência Rural, v.38, n.9, p.2441-2447, 2008. Available from: <http://www.scielo.br/pdf/cr/v38n9/ a09cr151.pdf $>$. Accessed: Mar. 14, 2017. doi: 10.1590/S010384782008005000009 . 
ROSOLEM, C.A.; BASTOS, G.B. Mineral deficiency symptoms in cotton cultivar iac 22. Bragantia, v.56, n.2, p.377-387, 1997. Available from: <http://www.scielo.br/scielo.php?script=sci_artte xt\&pid=S0006-87051997000200017>. Accessed: Mar. 14, 2017. doi: 10.1590/S0006-87051997000200017.

SCHÜBLER, A. et al. A new fungal phylum, the Glomeromycota: phylogeny and evolution. Mycological Research, v.105, n.12, p.1413-1421, 2001. Available from: <http://www.sciencedirect. com/science/article/pii/S0953756208620262>. Accessed: Mar. 14, 2017. doi: 10.1017/S0953756201005196.

SIQUEIRA, J.O. etal. Stimulation of vesicular-arbuscular mycorrhiza formation and growth of white clover by flavonoid compounds.
New Phytologist, v.118, n.1, p.87-93, 1991. Available from: <http:// onlinelibrary.wiley.com/doi/10.1111/j.1469-8137.1991.tb00568.x/ abstract>. Accessed: Mar. 14, 2017. doi: 10.1111/j.1469-8137.1991. tb00568.x.

SOUSA, D.M.G.; LOBATO, E. Cerrado: correção do solo e adubação. Brasília: Embrapa Informação Tecnológica, 2004. p. 416.

THOMPSON, J.P. et al. Stunted cotton (Gossypium hirsutum L.) fully recovers biomass and yield of seed cotton after delayed root inoculation with spores of an arbuscular mycorrhizal fungus (Glomus mosseae). Australasian Plant Pathology, v.41, n.4, p431-437, 2012. Available from: <https://link.springer.com/article/10.1007/s13313-012-0137-3>. Accessed: Mar. 14, 2017. doi: 10.1007/s13313-012-0137-3. 